\title{
A projeção internacional da América do Sul
}

\section{JOSÉ FLÁVIO SOMBRA SARAIVA}

Marco histórico nas relações entre os países da região, a Reunião de Presidentes da América do Sul, ocorrida em Brasília, entre 31 de agosto e primeiro de setembro de 2000, transcorreu em ambiente de cordialidade e apreensão. A cordialidade traduz a herança de convivência pacífica da região sul-americana. Longínquo às grandes conflagrações internacionais do século $\mathrm{XX}$, portador de certa homogeneidade cultural, promotor de esforço de desenvolvimento econômico de base nacional e construtor de capital político que se expressa na maturidade das opções internacionais, o espaço sul-americano conforma-se como unidade geográfica e política positiva em sua inserção nas relações internacionais do mundo contemporâneo.

A apreensão emerge de duas circunstâncias perturbadoras para a região: a iminência de intervenção militar externa na região, sob os disfarces do Plano Colômbia e o açodamento da construção de uma área de livre comércio para o continente americano. Ambos os elementos de perturbação inibem o esforço de construção do espaço sul-americano ao modificarem o percurso histórico de afirmação autônoma, pacífica e nacional dos seus interesses na cena internacional.

O Instituto Brasileiro de Relações Internacionais (IBRI), atendendo à solicitação da chancelaria brasileira, participou do programa preparatório da Reunião de Brasília por meio de contribuição intelectual aos formadores de opinião que estiveram presentes ao evento, especialmente jornalistas e editores latinoamericanos, bem como representantes de grandes agências de notícias internacionais. Em evento organizado pela Assessoria de Comunicação Social do Ministério das Relações Exteriores, o IBRI contribuiu com um painel de discussão, na manhã do dia 28 de agosto, na Sala de Imprensa do Palácio Itamaraty, sobre os grandes temas da agenda da Reunião de Presidentes.

Mediado pelo Prof. Dr. José Flávio Sombra Saraiva, Diretor Geral do IBRI, o painel - intitulado “A projeção internacional da América do Sul” - contou com a presença do Prof. Dr. Amado Luiz Cervo, professor de História das Relações Internacionais da Universidade de Brasília e editor da Revista Brasileira de Política Internacional (RBPI); do Prof. Dr. Francisco Monteoliva Doratioto, professor do Instituto Rio Branco; e do Prof. Alcides Costa Vaz, coordenador do Núcleo de Estudos do Mercosul da Universidade de Brasília.

Saraiva chamou a atenção para o fato de que, por três razões principais, esperava-se muito da Reunião de Presidentes, convocada pelo presidente Cardoso. 
Em primeiro lugar, a reunião representa um marco de invulgar dimensão política para o lançamento das bases de um bloco sub-continental, inevitável diante das novas forças que operam o sistema internacional na passagem do milênio. O eventual novo bloco, no entanto, terá ainda um longo e tortuoso caminho a percorrer no sentido de assegurar sua viabilidade prática e econômica.

Em segundo lugar, a reunião é produto dos ganhos políticos e econômicos da construção de duas realidades sub-regionais na América do Sul: a Comunidade Andina e o Mercosul. Os dois experimentos de integração, apesar das suas dificuldades de conjuntura - ou mesmo de alguns problemas estruturais decorrentes das próprias debilidades intrínsecas das suas sociedades e dos Estados representam um certo capital de negociação que pode se constituir em substrato considerável para o novo diálogo sul-americano. Nesse sentido, a única maneira para garantir a entrada gradual, com algum ganho para a América do Sul, na área de livre comércio das Américas (ALCA), sob a inspiração de Washington, seria aquele que partisse dos ganhos reais produzidos no interior dos processos de integração sub-regionais. Sem ganhos de competitividade e cautelas nas áreas produtivas nacionais, a conseqüência da aceitação da ALCA, como proposta pelos Estados Unidos, seria semelhante à de um suicídio político para as nações sulamericanas.

Em terceiro lugar, o esforço regional não se prende exclusivamente aos aspectos comerciais e tarifários. A Reunião de Brasília, ao incluir temas como o da construção de uma infra-estrutura regional e o do fortalecimento da democracia na região, ampliou o leque de convergência em torno da dimensão política em detrimento do "economicismo" da discussão em torno da oportunidade da inserção da região em uma área de livre comércio para as Américas. A construção de uma nova infra-estrutura para a integração - que passa pela articulação de grandes projetos, como o gasoduto Brasil - Bolívia, a Estrada de Ferro Santa Cruz de la Sierra - Santos, a Estrada Arco Norte (Boa Vista - Macapá, passando por Suriname, Guiana e Guiana Francesa), a Estrada Manaus - Caracas, a Estrada Transpacífica (Rio Branco - Peru), além do corredor biooceânico do Mercosul - é estímulo ao fomento de um novo ciclo de modernização industrial e de desenvolvimento econômico sustentado na região.

Cervo observou o ciclo histórico da projeção internacional da América Latina neste século, com ênfase no espaço sul-americano. Em especial, mencionou a superação, na década presente, do ciclo do nacional - desenvolvimentismo e de uma inserção do conjunto latino-americano em base mais positiva e construtiva no sistema internacional. A violência do ciclo liberal do presente estaria transtornando negativamente a capacidade empreendedora da região e vinculando-a, cada vez mais, a modelos de inserção periférica. Nesse contexto, os espaços de manobra para a criação de uma área sul-americana de livre comércio e, mais ainda, de um bloco econômico sub-continental, são ainda bastante precários. 
Nesse sentido, insistiu Cervo, seria necessário reconverter o padrão de inserção internacional e imaginar um processo de integração sul-americano que lembrasse o europeu dos anos cinqüenta. Em outras palavras, o espaço sulamericano necessita organizar-se em termos produtivos e não simplesmente no âmbito comercial. Empreendimentos que vinculem grandes empresas nacionais e capitais produtivos em uma verdadeira reconversão das capacidades para um novo patamar de desenvolvimento regional aberto são soluções ainda disponíveis no quadro das opções internacionais do presente.

Costa Vaz mencionou o forte valor estratégico da iniciativa que culminou com a Reunião de Brasília. Em primeiro lugar, a presença inédita dos chefes de Estados dos doze países sul-americanos na capital brasileira expressa a maturidade produzida ao longo dos quarenta anos de experimento de integração na região, iniciando-se com a ALALC em 1960. A estratégia do passado, de forte valor instrumental diante de quadros externos hostis, pode ser reconstruída no presente por meio do ajuste de uma inserção ativa, visando o desenvolvimento e uma presença internacional mais consonante com as potencialidades da América do Sul.

Nesse sentido, para Costa Vaz, o mecanismo de negociação em favor de um bloco sul-americano deve partir dos experimentos concretos dos dois processos de integração sub-regionais. Assim, o Mercosul necessitaria ser fortalecido, suas pendências e contenciosos necessitam ser tratados para que a iniciativa brasileira possa levar a dimensão bem sucedida do experimento sub-regional para o plano regional e sub-continental. Da mesma forma, no que se refere à Comunidade Andina, a superação das tensões relativas à democratização e à normalização política de Estados à beira de guerras civis seria o lastro em torno do qual se prepararia o campo para uma construção positiva do espaço sul-americano.

Doratioto, ao concluir a discussão, defendeu a valorização política do Mercosul como um fator de agregação ao projeto da formação de um espaço sulamericano. Não escondeu sua preocupação com os impasses do processo de integração sub-regional, especialmente a ampla crise econômica argentina, que dificulta a discussão de políticas de concertação e de arranjos macroeconômicos mais permanentes. A expectativa positiva, criada pelos negociadores brasileiros no Mercosul, em relação à nova administração daquele país, parece claudicar diante da aguda situação econômica em que se encontra a Argentina. Nesse quadro de vulnerabilidade, a idéia de um novo espaço sul-americano se enfraquece.

A contribuição dos membros do IBRI ao debate foi a mais produtiva. Os formadores de opinião presentes ao encontro, convidados pelo Ministro Luiz Fernando Ligiéro, assessor de comunicação social do Ministério das Relações Exteriores e membro da diretoria do IBRI, ampliaram o quadro das contribuições anteriores por meio de perguntas e comentários. Alguns deles estiveram certamente difundidos em vários dos órgãos de comunicação que, em especial da América Latina, fizeram a cobertura jornalística da Reunião de Presidentes da América do 
Sul. O IBRI cumpre, assim, sua função marcante, desde sua origem no Rio de Janeiro, em 1954, de desempenhar um relevante papel na difusão dos temas atinentes às relações internacionais e à política exterior do Brasil.

Setembro de 2000 